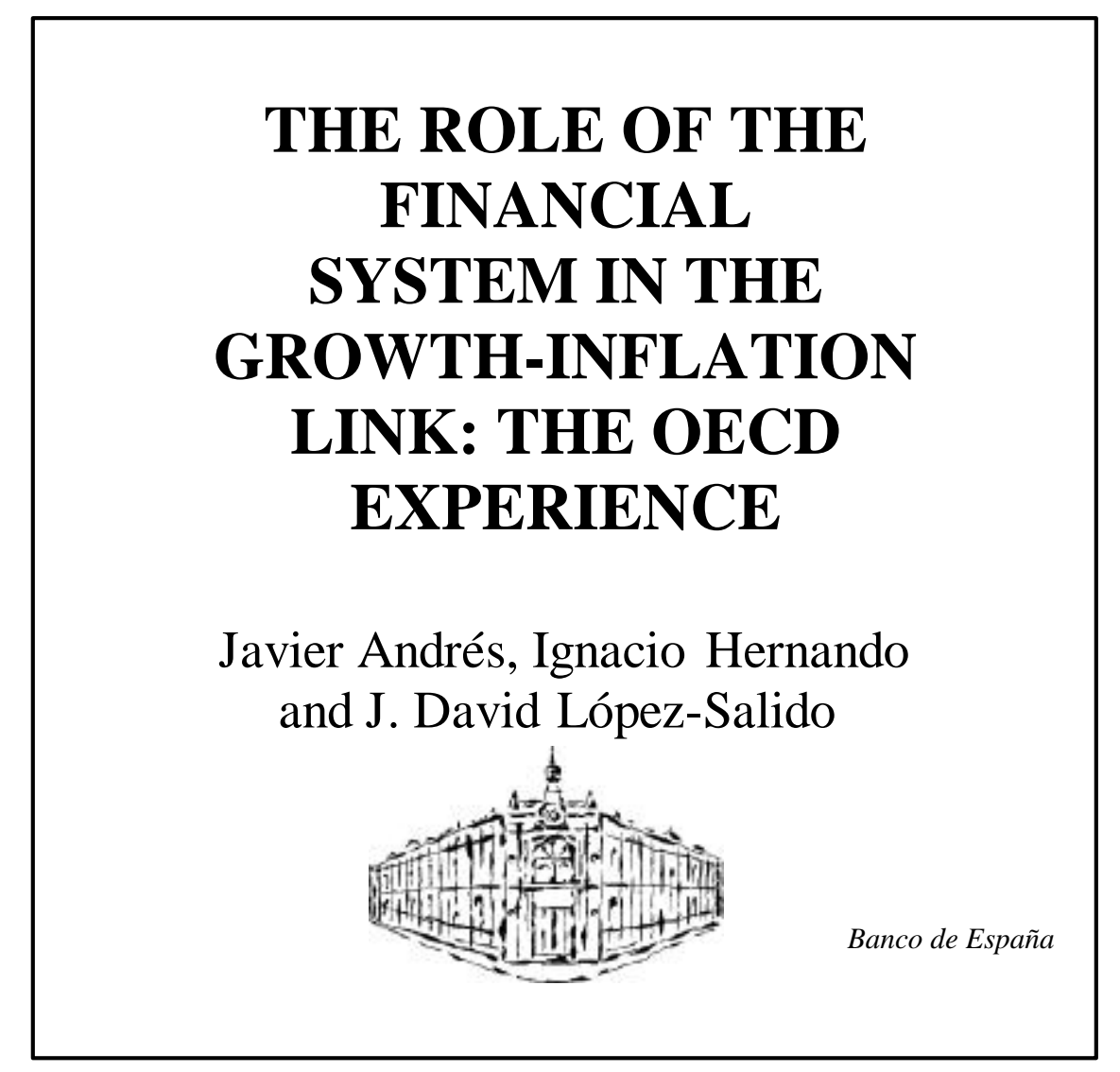

Banco de España - Servicio de Estudios

Documento de Trabajo n. ${ }^{\circ} 9920$ 


\title{
THE ROLE OF THE FINANCIAL SYSTEM IN THE GROWTH-INFLATION LINK: THE OECD EXPERIENCE (*)
}

\author{
Javier Andrés ${ }^{(1)}$, Ignacio Hernando ${ }^{(2)}$ and J.David López-Salido ${ }^{(2)}$ \\ (1) Banco de España and Universidad de Valencia \\ (2) Banco de España, Research Department
}

October 1999

$\left(^{*}\right)$ We thank the comments of Juan Ayuso, Javier Vallés, José Viñals, seminar participants at the Banco de España, and specially those of Jorge Martinez to a previous version. We also thank David Cubedes for research assistance. The views expressed in this paper are the authors' and do not necessarily reflect those of the Banco de España. All the data and programs used in the paper are available from the authors upon request. 


\title{
THE ROLE OF THE FINANCIAL SYSTEM IN THE GROWTH-INFLATION LINK: THE OECD EXPERIENCE (*)
}

\author{
Javier Andrés ${ }^{(1)}$, Ignacio Hernando ${ }^{(2)}$ and J.David López-Salido ${ }^{(2)}$ \\ (1) Banco de España and Universidad de Valencia \\ (2) Banco de España, Research Department
}

\begin{abstract}
The main contribution of this paper is to jointly estimate the effects of financial development and inflation on growth. We aim to exploit both the cross-section and the time-series dimension of the data on inflation, growth and some banking and stock market indicators over the period 1961-1993 for a sample of OECD countries. Overall, the results indicate, first, that the long-run costs of inflation are not explained by policies of financial repression, and second, that if inflation affects growth through its interaction with financial market conditions, this is not the only (nor the most important) channel.
\end{abstract}

Keywords: inflation, growth, financial market frictions, financial repression.

JEL Classification: O16, F43, E31 


\section{Introduction}

The joint evolution of inflation, financial development attained by an economy and its rate of growth can be viewed as the outcome of the decisions made by private agents, the policy actions carried out by the public sector and the shocks hitting each economy during a given period. Despite this joint determination, the empirical growth literature has separately approached the study of the links among these variables by estimating the effect of financial development and inflation on growth. Looking at these links separately within the framework of otherwise standard convergence regressions, two facts seem firmly established on empirical grounds: first, that the development of the financial sector in an economy fosters growth and, second, that high inflation harms growth.

The long-run incidence of financial development has been discussed in a short but insightful series of papers that find a significant positive correlation among growth and a set of indicators for both banking and stock market development. Although these papers focus mainly on the cross-country correlation among these variables, the direction of causality seems to be running from finance to growth, rather than the other way round (King and Levine (1993 a, b)). Following the seminal works by Barro (1995) and Fischer (1993), the link between inflation and growth has been extensively studied but their results are far more controversial. The controversy has fostered the empirical work in this field. A fair balance of these results indicates that inflation rates account for a small but significant proportion of the total variance of growth rates. Although causality may be running both ways, the negative effect of current inflation upon future growth rates cannot be rejected at standard significance levels.

These two strands of the empirical literature have lived separate lives. This is somewhat surprising, for one thing because some models indicate that policies of financial repression ${ }^{1}$ have adverse effects on long-run growth and are also associated to high inflation rates. In particular, high inflation rates are usually considered as indicators of the intensity of such repression. According to the implications of this class of models, the negative mediumterm correlation among inflation and growth might be driven by a third one, namely by the extent to which the public sector seeks to finance large deficits by imposing unwarranted

\footnotetext{
1 Financial repression policies include inflationary taxation, mandatory purchases of public debt, ceilings on interest rates and other regulations of the financial system. See Roubini and Sala-i-Martin (1995) for details.
} 
regulations to the banking system. According to other models, the only substantial long-run effect of inflation comes through its interaction with the financial system. In either case, the negative effect of inflation rates must statistically vanish in equations including financial market indicators since the latter would already pick up those effects.

Our work is closely related to that of Boyd, Levine and Smith (1996) and Haslag and Koo (1999) who study the joint dynamics of inflation, growth and financial depth with slightly different objectives. Boyd, Levine and Smith's main concern is to ascertain whether high inflation hinders financial development, whereas Haslag and Koo assess the empirical validity of the growth-financial development link to the presence of financial repression indicators, the rate of inflation among them. Both papers conclude that the development of the financial system is negatively affected by past inflation; additionally, Haslag and Koo find that inflation is never significant in growth regressions also including financial development and/or financial repression (the reserve requirement ratio) indicators. These results reinforce the empirical validity of the growth-financial development link but contribute to cast some doubts on that running form inflation to growth. The main contribution of this paper is to jointly estimate the effects of financial development and inflation on growth. More precisely, we try to ascertain whether the estimated negative long-run effect of inflation on growth withstands the presence of banking and stock market indicators in otherwise standard convergence regressions. We test this hypothesis using time series data on inflation, growth and some banking and stock market indicators over the period 1961-1993 for a sample of OECD countries in order to exploit both the cross-section and the time-series dimension of the data. We focus on OECD countries because we are interested in the role of the financial system in industrialized economies which is presumably different from that role in countries in the early stages of the development process.

We rely on two somehow complementary empirical approaches. First, we describe the statistical links among inflation, growth and banking system development in terms of Granger causality tests performed on tri-variate VAR models estimated allowing for the presence of country specific effects. The results show that, for our sample of industrialised economies, the link among finance development and growth is less reliable than it is usually meant, whereas that running from inflation to growth seems to be more robust. However, since we are dealing with endogenous variables, with a no clear-cut pattern of causality, sample correlations are not enough. Thus, our second exercise consists of including inflation and financial market variables in the growth regression empirical framework. Moreover, we augment the empirical model to allow for cross-country heterogeneity and we estimate by 
instrumental variables to take into account the simultaneity among the considered variables. Overall, the results indicate, first, that the long-run costs of inflation are not explained by policies of financial repression, and second, that if inflation affects growth through its interaction with financial market conditions, this is not the only (nor the most important) channel.

An important point is worth emphasizing in interpreting these results. We have made use of the set of proxies for financial development that is standard in the empirical literature. This choice is justified in order to make comparisons with other empirical work easier. However, this choice is far from being unquestionable. On the one hand, these standard indicators do not cover all the agents or institutions that provide financial services (for instance, bond markets or insurance companies are not represented in these indicators). On the other hand, these indicators are mainly measuring the size of the institution or market, but it would also be desirable to use measures of efficiency of the financial system as well. We believe that these shortcomings are behind the weakness of the finance-growth relationship we have found for our sample of OECD countries. In our view, the construction of indicators that properly capture the efficiency of the financial system is an issue that deserves further research.

After this introduction the paper is organised as follows. Section 2 briefly surveys the theoretical and empirical results linking inflation, growth and financial system development. The analysis of causality is discussed in Section 3, whereas Section 4 presents the estimated effects of including inflation and financial variables in otherwise standard growth equations. Finally, the main conclusions of the exercise are summarised in Section 5.

\section{The theoretical and empirical background}

There are few models in which economic growth and financial development are jointly determined ${ }^{2}$. Most of the theoretical work in this field deals with the potential impact of financial development on growth assuming the former to be exogenous. McKinnon (1973) and Shaw (1973) were among the first to provide insightful theoretical foundations for the fact that the liberalisation and development of financial markets favour economic growth ${ }^{3}$.

\footnotetext{
${ }^{2}$ Greenwood and Jovanovic (1990) and Saint-Paul (1992) are remarkable exceptions.

${ }^{3}$ In his pioneering Theory of Economic Development, Schumpeter argued that the services provided 
Subsequent theoretical work has studied in depth this direction of causality running from financial development to economic growth. The different mechanisms which explain how financial intermediation can affect growth may be classified in three groups: effects on the saving rate, effects on the proportion of saving funnelled to investment and effects on the efficiency in the allocation of capital ${ }^{4}$.

Since the seminal work by Goldsmith (1969), numerous empirical studies have analysed the relationship between the level of financial markets development and the rate of growth making use of large cross-country data sets. A strong positive correlation between growth and indicators of financial development has been recurrently obtained, even after controlling for most of the factors that have been usually considered as determinants of growth ${ }^{5}$.

The long-run effects of inflation have been studied in a similar framework (Orphanides and Solow, 1990 and De Gregorio, 1993). Besides the fact that a high and volatile inflation reduces the real rate of return of capital and undermines the confidence of domestic and foreign investors, inflation also affects the accumulation of other determinants of growth such as human capital or $R+D$ investment. This channel constitutes what is known as the accumulation or investment effect of inflation on growth. But, over and above these effects, inflation also worsens the long-run macroeconomic performance of market economies by reducing the efficiency with which productive factors are used. This is the so called efficiency channel, according to which higher inflation induces bigger forecast errors by distorting the information contents of prices, so encouraging economic agents to devote more time and resources to gather information and to protect themselves against the damages caused by price instability. This endangers the efficient allocation of resources.

From an empirical point of view, a series of recent papers have addressed the study of the long-run influence of inflation on growth within the framework of convergence

by financial intermediaries play a decisive role enhancing productivity and fostering growth.

${ }^{4}$ See Pagano (1993), Berthélemy and Varoudakis (1996) and Levine (1997) for surveys of the theoretical arguments supporting the link between financial development and long-run growth.

${ }^{5}$ The empirical literature has focused either on measures of banking activity (King and Levine (1993a,b)) or on measures of stock market development (Atje and Jovanovic (1993) and Levine and Zervos (1998)). In both cases the statistical association between the growth rate and the financial indicators seems to be equally robust. 
equations developed by Barro and Sala-i-Martin (1991) and Mankiw, Romer and Weil (1992). Fischer (1993) and Barro (1995) are seminal papers among those that estimate cross-country convergence regressions augmented by the inflation rate. The main findings of this body of empirical literature may be summarised as follows. First, inflation has a negative temporary impact upon long-term growth rates; this effect is significant and generates a permanent reduction in the level of per capita income. Second, inflation not only reduces the level of investment but also the efficiency with which productive factors are used $^{6}$.

In contrast to the previous models that focus on genuine effects of financial development and inflation on economic growth, two classes of models deal simultaneously with the role of these two variables in the process of growth. On the one hand, a recent wave of theoretical articles has focused on the effects of inflation on growth that arise through its interaction with financial markets. These papers show different channels whereby high inflation exacerbates informational frictions afflicting financial markets, thus, depressing the level of activity and generating a significant cost in terms of future growth rates. De Gregorio and Sturzenegger (1994a,b) present models in which the ability of financial intermediaries to distinguish among heterogeneous firms is reduced as inflation rises leading to a larger share of credit allocated to less efficient firms. In contrast, in the paper by Choi, Smith and Boyd (1996) inflation reduces real returns to savings and makes more severe the adverse selection problems in capital markets inducing a higher degree of credit rationing. Finally, Huybens and Smith (1999) present a monetary growth model with a different kind of informational friction. In their model, there are multiple technologies for producing capital and some of them are subject to a standard costly state verification problem. They show that, at the steady state, higher rates of money creation reduce the real return on all assets and, under certain conditions, lead to a reduction in the volume of trading in equity markets. All of these papers show to what extent financial market frictions may play a crucial role to understand the relationship between inflation and growth.

On the other hand, recent theoretical work provides an alternative explanation for the

\footnotetext{
${ }^{6}$ However, these results are far from being generally accepted and they have been criticized on several grounds. First, Levine and Renelt (1992) find that the statistical significance (and even the sign) of most variables (inflation among them) in growth equations are not invariant to changes in the information set. Second, Bruno and Easterly (1998), among other authors, argue that the negative correlation found between inflation and growth is explained by the experience of high-inflation economies. Additional criticisms can be found in Kocherlakota (1996) and Sims (1996).
} 
pattern of correlations among inflation, growth and financial markets development. This line of research argues that government strategies of financing large deficits resorting to policies of financial repression explains the negative correlation between inflation and the level of activity in financial markets. First, the repression of the financial system increases the transaction costs of converting illiquid to liquid assets and, as a consequence, expands money demand. This expansion raises the inflation tax base, generating incentives to inflate ${ }^{7}$. Moreover, these models predict that financial repression will also have adverse real effects to the extent that a badly functioning financial sector decreases the efficiency in the allocation of savings. As a consequence, these models suggest that the negative effect of inflation on growth is spurious as both high inflation and low economic growth are caused by policies of financial repression. In related theoretical research, Chari, Jones and Manuelli (1996) compare the implications of several quantitative models to explain the growth effects of inflation found in the literature. They conclude that inflation per se does not have significant effects on growth, but financial regulations and their interaction with inflation have substantial effects on growth.

Summing up, these models indicate that policies of financial repression have adverse effects on long-run growth and are also associated to high inflation rates. Thus, the negative correlation among these two variables is driven by a third variable. On the other hand, according to the models stressing financial market frictions, the real effects of inflation come through its interaction with the financial system, reducing the efficiency with which this sector operates and, thus, harming growth. If either of these were relevant channels through which inflation affects growth, the coefficient of the inflation rate in convergence equations should be dramatically affected by the inclusion of measures of financial development. Before we test this hypothesis, the next section is devoted to study the causality relationships among these variables.

\section{A first look at the data: Causality analysis}

\footnotetext{
${ }^{7}$ However, Espinosa and Yip (1996) present a model that generates a "Laffer curve" type relation between inflation and repression. Thus, in some cases (when financial repression is severe enough so that an informal financial sector emerges) liberalization may be inflationary. Roubini and Sala-i-Martin (1995) argue that policies of financial repression have two different effects: an increase in the inflation tax base (due to the increase in money demand) and a decrease in the income-tax rate (implied by a reduction in income). Thus, these authors suggest it is more likely that a government choose to repress the financial sector if tax evasion is large because in such a case the increase in the inflation tax base is not offset by a substantial reduction in the income-tax base.
} 
The construction of synthetic indicators of the volume of services provided by the financial system is not an easy task. First, because the services provided are very diverse (management of the payment system, mobilisation of savings, information gathering, risk diversification, exerting corporate control), and second because the agents that provide these financial services are also heterogeneous (banks, securities markets, insurance companies, among others). As a result, there is a wide spectrum of indicators of financial development used in the empirical literature ${ }^{8}$. In this paper, we use the set of proxies for banking development proposed by King and Levine (1993a,b) that has been recurrently used in most of the subsequent empirical work ${ }^{9}$. Additionally, we consider market capitalization as a measure of stock market development (Levine and Zervos (1998)). Thus, the data set includes annual variables for 21 OECD countries ${ }^{10}$ over the sample period $1961-1993$ with the only exception of market capitalization that is available for 16 countries $^{11}$ and only over the 1971-1993 period.

The data set incorporates three measures of banking system development (BTOT, DCPY, QLLY and RESERVES) and one indicator of stock market development (MKTCAP). ${ }^{12}$ The variable labelled QLLY is defined as the ratio of liquid liabilities (excluding currency in circulation and demand deposits) of the financial system to GDP. We consider this variable, as it is usual in the literature, as a proxy of financial depth since it represents the size of the formal financial intermediary sector. The implicit assumption is that the size of the financial system is positively related to the provision of financial services. The variable labelled DCPY is defined as the ratio of claims on the non-financial private sector to GDP. This measure tries to proxy the amount of credit available to the private sector through the banking sector. Implicitly we are assuming that the credit granted to the public sector may respond to different criteria from those used to grant credit to private agents. The variable labelled BTOT is defined as the ratio of deposit money bank domestic assets to deposit money bank

\footnotetext{
${ }^{8}$ See De Gregorio and Guidotti (1995) for a discussion of the advantages and shortcomings of different indicators of financial development.

${ }^{9}$ See Galetovic (1994), Berthélemy and Varoudakis (1996), Boyd, Levine and Smith (1996) and Levine (1997), among others.

10 The countries included in the analysis are the following: Australia, Austria, Belgium, Canada, Switzerland, Germany, Denmark, Spain, Finland, France, Greece, United Kingdom, Ireland, Italy, Japan, Netherlands, Norway, New Zealand, Portugal, Sweden and USA.

${ }_{11}$ MKTCAP is not available for Finland, Greece, Ireland, Portugal and New Zealand.

12 The Data Appendix lists financial variables sources and other variables used in the analysis.
} 
domestic assets plus central bank domestic assets. It tries to capture the importance of banks relative to the central bank. The idea behind the use of such variable is that deposit banks are more likely to provide risk sharing and information services than central banks. We have also constructed a variable labelled RESERVES which is defined as the ratio of claims on monetary authorities to demand deposits plus other deposits of banking institutions. We consider that this variable, even reflecting a policy instrument -the reserve requirement ratio-, can be also described as a proxy of the degree of financial development. The implicit hypothesis here is that countries with high reserve ratios have less developed financial systems than countries with low reserve ratios (in particular, Haslag and Koo (1999) have found evidence in favour of this hypothesis). Finally, we label MKTCAP to the ratio of domestic shares on domestic exchanges in a year divided by GDP. It measures the size of the stock market and it is the usual indicator of market development. This variable tries capture the fact that the stock markets provide services for growth that are different from those provided by banks.

Tables 1-3 present descriptive statistics on the four financial indicators, growth and inflation. Table 1 includes the information corresponding to the whole sample (21 countries over the 1961-1993 period) for which the banking indicators are available. Table 2 presents the statistic for a restricted sample (16 countries over the 1971-1993 period) given the limited availability of the stock market variable. When we divide observations in four quartiles defined in terms of the growth rate (Panel A of Tables 1 and 2) we first observe that contemporaneous financial indicators are not significantly correlated with growth rates. This result contradicts the results of King and Levine (1993a) using cross-section average data but seems to be consistent with Galetovic (1994) and De Gregorio and Guidotti (1995). Second, as we move from observations with lower growth to observations with higher growth we see a sizeable decrease in the average inflation rate (in the case of the whole sample). When we divide observations in four quartiles defined in terms of the inflation rate (Panel B of Tables 1 and 2) we observe that financial indicators are negatively, and in some cases significantly, correlated with inflation. Finally, Table 3 shows that financial indicators are highly and significantly correlated with each other. This is specially the case for the measures of banking development excluding RESERVES. Notice that while variables QLLY, DCPY and BTOT are aimed to proxy banking development, the variable RESERVES measures reserve requirements as an indicator of financial repression and it is negatively correlated with the proxies of financial development. For the later variables, the correlation coefficient among banking indicators ranges between 0.30 and 0.78 in the whole sample (and between 0.38 and 0.81 in the restricted sample). 
To analyse causality relationships among inflation, growth and financial system developments, we use the following unrestricted VAR model in describing the joint dynamics of the system:

$$
Y_{i t}=C_{i}+A(L) Y_{i t-1}+B(L) X_{i t}+U_{i t}
$$

where $Y_{i t}$ is a vector including the logarithm of per capita GDP ${ }^{13}$, the rate of inflation $\left(p_{i t}\right)$ and a financial variable $\left(F_{i t}\right), C_{i}$ is a constant (which we allow to differ among countries) and $U_{i t}$ is a vector of error terms i.i.d. with constant variance and zero mean. The vector $X_{i t}$ includes additional regressors usually suggested by growth theory. The lag-polynomial matrices $A(L)$ and $B(L)$ take the following form:

$$
A(L)=\left[\begin{array}{lll}
A 11(L) & A 12(L) & A 13(L) \\
A 21(L) & A 22(L) & A 23(L) \\
A 21(L) & A 32(L) & A 33(L)
\end{array}\right] ; B(L)=\left[\begin{array}{l}
B 1(L) \\
B 2(L) \\
B 3(L)
\end{array}\right]
$$

where $A_{i j}(L)$ is a lag polynomial of order $p$ such as

$$
A_{i j}(L)=a_{i j}^{1} L+a_{i j}^{2} L^{2}+a_{i j}^{3} L^{3}+\ldots+a_{i j}^{P} L^{P}
$$

Standard causality tests are run on the joint significance of the coefficients of $A_{i j}(L)$ matrices outside the main diagonal of matrix $A(L)$. Thus, for instance, the rejection of the null hypothesis that coefficients $A_{12}$ 's are zero indicates that current inflation helps to reduce the mean-square error in the prediction of per capita income, therefore, that $p$ causes $y$ in the Granger sense.

The elements of matrices $A(L)$ and $B(L)$ will be assumed to be homogeneous

\footnotetext{
${ }^{13}$ We include the level of per capita income instead of the growth rate of output because the effect found in the literature on inflation and growth is more properly a level effect (see Andrés and Hernando (1999) for a detailed discussion of this issue). Moreover, testing the causality to the growth rate only entails adding linear restrictions on the coefficients in $A_{j 1}(L)$, and writing per capita income in first differences. The results of the causality tests to the growth rate are quite similar to those of the causality tests to the level of per capita income and will not be reported here to save space.
} 
among countries. The estimation of (1) raises several methodological issues, the most important one being the possibility that some variables are non-stationary, in which case exclusion tests do not have a standard distribution. ${ }^{14}$ There are several ways in which the hypothesis of causality between integrated variables can be tested making use of statistics with asymptotic standard distribution (see, for details, Sims, Stock and Watson, 1990). The method proposed by Dolado and Lütkepohl (1996) does not require searching for cointegration vectors which is quite often a hazardous task in panel data models. These authors propose the OLS estimation of a VAR in levels of order $p+1$. The exclusion test performed on the $p$ first lags is thus distributed asymptotically as an $F$, whereby the loss of efficiency by the over-parameterisation of the model is compensated by the test's consistency and simplicity. The application of this method requires knowing the true order, $p$, of the VAR. In this paper, rather than discussing the structure of the lags in detail, we present results for a sufficiently broad range of lags that ensure the stationarity of the residuals. The model contains in all cases a bunch of additional regressors aimed at capturing other aspects of the macroeconomic stance that can help to forecast the future course of the variables of interest. The results are presented in Table 4 and may be summarised as follows.

First, the current rate of inflation provides relevant information on output prospects in OECD countries. The null of non-causality can be rejected in most cases at the $5 \%$ level of significance and in all cases at the $10 \%$. As regards the sign of the sum of the coefficients of lagged inflation in the output equation, the t-statistic is always negative and significant. Moreover, current output developments also help to explain the future course of the inflation rate. The t-statistic is in this case always positive and in most cases significant. These effects are robust to alternative financial variables being included in the VAR and to different lagstructures.

Second, things are different when analysing causality relationships from financial variables to output and the other way round. Causality from QLLY and DCPY to output is easily rejected at the $10 \%$ significance level. The test of causality from BTOT to output is less

14 Since this section applies annual data relating to the variables of interest, it departs from the traditional approach in the empirical literature on growth, which avoids using annual information. Nevertheless, an increasing number of studies tend to use raw annual data. Moreover, in the dynamic analysis of causality, models based on time averages can be considered as restricted versions of models that use annual data. As regards the role of individual effects in multi-country regressions, we shall take them into account in this section by considering a specification in which vector $\mathrm{C}$ include different constants for each country. 
conclusive but the t-statistic is either negative or non-significant or both. In this case, only the variable of market capitalisation helps to forecast future output. The t-statistic in this case is positive and unambiguously significant. Causality from output to financial variables is overwhelmingly rejected.

Finally, the causality relationships between financial variables and inflation are also far from conclusive. On the one hand, inflation does not help to predict future financial variable dynamics. This result is in contrast with a recent paper by Boyd, Levine and Smith (1996) who present evidence in favour of a strong negative association between inflation and financial market performance. On the other hand, two out of the four financial variables considered help (at least for some lag-structures) to predict future inflation. However, this result is not very robust to the lag structure. Moreover, the sum of the coefficients of past financial variables in the inflation equation differs also considerably across models: it is negative for BTOT, positive, and in some cases significant, for QLLY and DCPY and it changes signs for the different models including MKTCAP.

These results give weak support to the link among finance development and growth, whereas they confirm that running from inflation to growth. ${ }^{15}$ Moreover, the causality results are not in favour of the close relationship between inflation and financial development suggested by the models stressing financial market frictions ${ }^{16}$.

\section{Inflation and finance in augmented convergence equations}

In this section we turn our attention to more standard convergence equations suitably augmented to include both the inflation rate as well as some indicators of financial development. Although the analysis carried out in the previous section gives a first account of the dynamic relationship among the variables of interest, the issue of causality cannot be fully settled in that empirical setting. In order to asses the long-run effect of inflation on output, the estimation of convergence equations is the natural approach, both because it is a

\footnotetext{
15 These results are also confirmed by the inclusion of RESERVES in the analysis. See the causality tests presented in Appendix 2 (Table 4.A).

${ }^{16}$ As an alternative to the OLS with country dummies procedure used, we also tried the strategy followed by Rousseau and Wachtel (1998). This strategy consists in estimating equation (1) in first differences by the generalized method of moments (GMM). Using this procedure yields a much lower the level of significance of the causality tests.
} 
long run effect what we are looking at and because most of the work done in this field has adopted this framework. Also, growth equations focus in a particular way of causation, i.e. that running from inflation and finance to growth, which is the one we are interested in. We estimate linear versions of the convergence equations making use of four-year averages of the raw annual data (expressed in logs) covering the period 1961-1992. More precisely, in this specification the growth rate of per capita income is regressed on the initial level of per capita income, the rate of investment, the rate of schooling, the growth rate of population, a linear trend and a constant. In order to test the effects of interest, we augment these equations with the inflation rate and with some indicators of financial development.

Table 5 shows the OLS estimates of the convergence equation augmented with inflation and/or financial system indicators. To save space, we only present the coefficient estimates for inflation and financial development indicators. The other explanatory variables enter the regressions as predicted by the neoclassical growth model. The parameter of initial per capita income is negative and highly significant. The coefficients of the input accumulation rates have the expected sign, although the one for population is nonsignificant. The estimated parameter of the trend, which according to the theoretical model is approximating the rate of technological progress, has an unexpected negative sign. ${ }^{17}$ Regarding the effects of interest, the coefficient of the inflation rate is negative and significant when including financial system indicators. The size of the coefficient does not change significantly when these indicators are included. The coefficients of the proxies of financial development are all positive but only BTOT is significant at the $5 \%$ level of significance (MKTCAP is so at $10 \%$ ). These results are not fully consistent with those of King and Levine (1993a) for a larger sample. When inflation is included among the right hand side variables two results are worth noting. First, the coefficients of the financial development indicators are always positive although none of them is significant, ${ }^{18}$ and second, the coefficient of inflation is always negative and significant and is not dramatically affected by the presence of either

\footnotetext{
17 A possible interpretation is that the trend may be capturing the process of sustained reduction in the rate of growth in per capita income suffered by OECD countries during part of the sample period. See, for a similar result, Andrés and Hernando (1999).

18 When the financial development indicators are simultaneously included their significance is jointly rejected. The $p$-value for the F-test of the joint exclusion of QLLY, BTOT and DCPY is 0.11 $(0.55)$ in an equation excluding (including) the inflation rate. The $p$-value for the F-test of the joint exclusion of QLLY, BTOT, DCPY and MKTCAP is $0.15(0.09)$ in an equation excluding (including) the inflation rate.
} 
QLLY, BTOT or DCPY in the model. ${ }^{19}$

Overall, these results indicate, first, that it seems to be a genuine effect of inflation on growth and, second, that the development of the financial system could favour economic growth. Both effects are apparently not related, although if any the former seems to be stronger. However, before to draw any conclusion out of these estimates it is convenient to take a closer look at these relationships, trying to correct for some biases that might arise in these specifications. In particular, we address two of the most common criticisms to the empirical framework adopted. First, we augment the empirical model to allow for crosscountry heterogeneity and, second, we estimate by instrumental variables to take into account the simultaneity among the considered variables.

There are several reasons to include individual effects in convergence equations estimated with multi-country data sets. ${ }^{20}$ The very existence of differences in the rates of technical progress or, as it is more likely, in the initial conditions of each country, would lead to the presence of idiosyncratic effects in growth equations. As a result, the consideration of individual effects might alter significantly the estimates of the convergence equations. Then, it is interesting to test if the estimates in Table 5 are affected by the omission of these country-specific (time-invariant) effects. For this reason, in Table 6 we present estimates of the fixed effects models, which we compute including a dummy variable for each country in the linear convergence equation. Again, to save space, we only present the coefficient estimates for inflation and financial development indicators. A substantial change to note as compared the previous model is the change in the estimated coefficient of the trend that now recovers its expected positive sign; the coefficient is in some cases significant, with a point estimate of around 0.01 . The parameters of the initial per capita income and of the accumulation rate of physical capital are higher in absolute value and the coefficients of the accumulation rate of human capital and of population growth are non-significant.

The coefficient of the inflation rate remains negative and significant and its size is lower than that obtained for the model without individual effects. Moreover, given that the coefficient of initial per capita income is now twice as large as the one of the model without

\footnotetext{
${ }^{19}$ The fall in the coefficient of inflation in column (8) has more to do with the reduced sample in this equation than with the presence of MKTCAP on it.

${ }^{20}$ See Knight, Loayza and Villanueva (1993) and Islam (1995).
} 
country dummies, the long-run cost of inflation is now lower. ${ }^{21}$ On the contrary, the coefficients of the indicators of financial development become non-significant or, in some cases wrongly signed, the only exception being that of MKTCAP which is positive and significant (both with and without inflation among the regressors). ${ }^{22}$

The OLS estimates of the effects of inflation and financial system development on growth, presented in Tables 5 and 6, may exhibit a non-negligible simultaneity bias. First, inflation and growth are the joint outcome of the way in which an economy responds to different shocks and, similarly, there are also "third factors" (legal systems, political institutions, technological innovations, among others) driving both financial and economic development. Second, regarding the inflation-growth and financial development-growth relationships, the theoretical literature presents arguments in favour of causality in both directions, some of which have been confirmed by our results in section 3. As discussed by Harris (1997) the standard procedure of choosing the initial value of a variable as the instrument of its value throughout the period may lead to misleading results. In particular, in the context of financial and growth models, it can overstate the statistical significance of financial indicators. To avoid this, Harris proposes to run 2SLS using lagged values as instruments for the endogenous ones. Tables 7 and 8 present the results of the models estimated by instrumental variables. Equations in Table 7 do not include country-specific effects whereas those in Table 8 allow for these effects. Comparing results in Tables 5 and 7 (OLS and IV estimates of models without country-specific effects) some interesting results arise. First, the coefficient of inflation is negative and significant and its size is almost twice as large as that obtained in the OLS estimation. This result is consistent the causality tests in section 3 in which a positive causality running from income to inflation was detected, thus leading to a simultaneity downward bias in the OLS estimation of the inflation costs. Second, in the IV estimation the coefficients of financial development proxies are not significant; only BTOT is close to the $10 \%$ level of significance when inflation is not included in the

\footnotetext{
${ }^{21}$ This time though the transition period is much shorter since a higher coefficient of initial per capita income means that convergence to the steady state is much faster too.

22 When the financial development indicators are simultaneously included they are jointly significant. Nevertheless this result is mostly driven by the significance of the DCPY which is wrongly signed. The p-value for the F-test of the joint exclusion of QLLY, BTOT and DCPY is 0.007 (0.001) in an equation excluding (including) the inflation rate. The p-value for the F-test of the joint exclusion of QLLY, BTOT, DCPY and MKTCAP is $0.004(0.002)$ in an equation excluding (including) the inflation rate.
} 
specification (column 2 of Table 7). ${ }^{23}$ This might imply that the observed positive effect of financial development on growth could be attributed, in our sample, to reverse causation (from growth to financial development). Similar conclusions can be reached from the comparison of Tables 6 and $8 .^{24}$ In this case, the implicit downward bias in the OLS estimation of the inflation costs is even larger, again the inflation rate stands as the only additional regression in the convergence equation which keeps a reasonable explanatory power of growth rates in OECD economies. ${ }^{25}$ This would suggest that, for our sample of industrialised economies, the interaction of inflation with financial market variables is not a relevant mechanism to explain the effects of inflation on long-run growth. This result is consistent with Galetovic (1994) and De Gregorio and Guidotti (1995). These authors show that the positive correlation between financial indicators and growth is considerably weaker for industrialised countries, suggesting that the positive effect of financial development is especially relevant in the early stages of the development process. These results are also consistent with those of Harris (1997) who finds only a weak significance of stock markets indicators in growth regressions for developed countries (MKTCAP in our model).

\section{Conclusions}

The empirical growth literature has focused in two particular links among inflation, growth and financial variables, namely the effect of financial development and of inflation on growth. In this paper we analyze the joint dynamics of these variables with the purpose of assessing the robustness of the inflation-growth link in developed countries. Our main contribution is the joint analysis of the effects of financial development and inflation on growth. We address this issue making use of a panel of OECD countries covering the period 1961-1993 and exploiting both the time-series and the cross-section dimension of the data. Furthermore, we augment the empirical model to allow for cross-country heterogeneity and we estimate by instrumental variables to take into account the simultaneity among the considered variables.

${ }^{23}$ Both in Table 7 and 8, when the financial development proxies are simultaneously included they are jointly rejected at the 10 per cent level in most cases.

\footnotetext{
${ }^{24}$ This is also the case when we include the variable RESERVES in the analysis. See Appendix 2 (Table 8.A) for details.

${ }^{25}$ In column (8) the t-ratio of the inflation rate is (1.32). Nevertheless, this low value is not only caused by the presence of MKTCAP in the regression, but also by the short sample used to estimate this model (16 countries and a shorter period, further reduced by the use instruments).
} 
Our analysis shows that the negative effect of inflation in growth equations remains significant even after including financial market variables. Additionally, the link between proxies of financial market performance and growth is found to be weak, vanishing when country-dummies are included and endogeneity is accounted for using instrumental variables. Also, controlling for inflation reduces the significance of those indicators. Overall, these results indicate, first, that the long-run costs of inflation are genuine and not explained by a sort of omitted variable bias. These costs are not explained by policies of financial repression and although they may stem from the interconnection among inflation and financial market conditions, this is not the only (nor the most important) channel.

In addition, our analysis has not found a significant positive growth-financial development link. There are three potential reasons for the lack of significance of this relationship in our analysis. First, the finance-growth link might be less relevant for industrialized countries with already highly developed financial systems. Second, the standard analysis of the finance-growth link does not correct the specification biases that might arise when cross-country heterogeneity and simultaneity among the considered variables are not taken into account. Finally, the proxies for financial development used in our analysis - which are the standard indicators in the empirical literature- might be adequate when analyzing large samples of countries, but might be too rough when focussing in a smaller and more homogeneous sample of countries, like our panel of OECD countries. In particular, we believe that the impact of financial markets on economic growth is more sophisticated than what these standard variables capture. On the one hand, these standard indicators do not cover all the agents or institutions that provide financial services. On the other hand, these indicators are mainly measuring the size of the institution or market without properly capturing the efficiency of the financial system. In our view, the construction of indicators of the efficiency of the financial system and the analysis of its impact on the process of economic growth are issues that deserve further research. 


\section{Appendix 1: Data Sources}

Financial Variables:

- BTOT: IMF's International Financial Statistics corresponding to lines $(22 a+22 d) /(12 a+22 a+22 d)$.

- DCPY: IMF's International Financial Statistics corresponding to lines 32d/99.

- QLLY: IMF's International Financial Statistics corresponding to lines 35/99.

- RESERVES: IMF's International Financial Statistics corresponding to 20/(24+25).

- MKTCAP: Morgan Stanley Capital International.

Non-Financial Variables:

Those were taken from OECD data set (see, for details, Andrés and Hernando (1999) and Dabán, Doménech and Molinas (1997)):

- $\quad$ Per capita GDP

- Growth rate of per capita GDP

- Inflation rate

- Investment rate

- Rate of schooling

- Growth rate of the population

- Money growth

- Exports growth

- Public spending as a percentage of GDP 


\section{Appendix 2: Robustness to the inclusion of variable RESERVES}

In this Appendix we show that our results do not change significantly when we include the variable RESERVES in our empirical analysis. We show both the causality test and the IV estimation including fixed effects.

Table 4.A. CAUSALITY TESTS

\begin{tabular}{|c|c|c|c|c|c|c|c|c|c|c|c|c|}
\hline \multirow[b]{3}{*}{$P$} & \multicolumn{4}{|c|}{ Causality from inflation to } & \multicolumn{4}{|c|}{ Causality from output to } & \multicolumn{4}{|c|}{ Causality from RESERVES to } \\
\hline & \multicolumn{2}{|c|}{ Output } & \multicolumn{2}{|c|}{ RESERVES } & \multicolumn{2}{|c|}{ Inflation } & \multicolumn{2}{|c|}{ RESERVES } & \multicolumn{2}{|c|}{ Output } & \multicolumn{2}{|c|}{ Inflation } \\
\hline & $F(\%)$ & $\mathrm{t}$ & $F(\%)$ & $\mathrm{T}$ & $F(\%)$ & $\mathrm{T}$ & $F(\%)$ & $\mathrm{T}$ & $F(\%)$ & $\mathrm{t}$ & $F(\%)$ & $\mathrm{T}$ \\
\hline 3 & 0 & -4.59 & 11 & 1.31 & 0 & 1.35 & 38 & -0.72 & 48 & -1.47 & 48 & 0.97 \\
\hline 4 & 0 & -3.80 & 19 & 0.82 & 0 & 4.70 & 4 & -2.98 & 61 & 0.18 & 47 & 0.75 \\
\hline 5 & 0 & -4.88 & 27 & 0.92 & 0 & 0.28 & 4 & -1.89 & 43 & -0.92 & 44 & -0.34 \\
\hline
\end{tabular}

Note: See Table 4

Table 8.A. CONVERGENCE EQUATION WITH INFLATION AND RESERVES (INCLUDING COUNTRY EFFECTS)

\begin{tabular}{lcccc}
\hline & \multicolumn{3}{c}{ OLS } & \multicolumn{2}{c}{ IV } \\
\hline \multirow{2}{*}{ INFLATION } & $(1)$ & $(2)$ & $(3)$ & $(4)$ \\
& - & $-\mathbf{0 . 0 0 2 5}$ & - & -0.0063 \\
RESERVES & -0.042 & -0.068 & -0.1470 & -0.022 \\
& $(0.41)$ & $(0.68)$ & $(0.81)$ & $(0.13)$ \\
$R^{2}$ & 0.66 & 0.68 & 0.55 & 0.62 \\
$\mathrm{~S}$ & 0.045 & 0.045 & 0.049 & 0.045 \\
\hline
\end{tabular}

Note: See Tables 6 and 8. 


\section{REFERENCES}

Andrés, J. and I. Hernando (1999): "Does inflation harm economic growth? Evidence for the OECD", in The Costs and Benefits of Price Stability, M. Feldstein (ed.), University of Chicago Press.

Atje, R. and B. Jovanovic (1993): "Stock markets and development", European Economic Review, 37, 632-640.

Barro, R. (1995): "Inflation and economic growth", Bank of England Economic Bulletin, 1-11.

Barro, R. and X. Sala-i-Martín (1991): "Convergence across states and regions", Brookings Papers on Economic Activity, 1, 107-182.

Berthélemy, J.C. and A. Varoudakis (1996): Financial Development policy and growth, OECD Development Centre Studies, Long-Term Growth Series

Boyd, J., R. Levine and B. Smith (1996): "Inflation and Financial Market Performance", Federal Reserve Bank of Cleveland WP 9617.

Bruno, M. and W. Easterly (1998): "Inflation crises and long-run growth", Journal of Monetary Economics, 41, 3-26.

Chari, V., L. Jones and R. Manuelli (1996): "Inflation, growth and financial intermediation", Federal Reserve Bank of St. Louis Review, May/June 1996, 41-64.

Choi, S., B. Smith and J. Boyd (1996): "Inflation, financial markets and capital formation", Federal Reserve Bank of St. Louis Review, May/June 1996, 9-39.

Dabán, T., R. Doménech and C. Molinas (1997): "International and Intertemporal comparisons in OECD countries: A growth sensitivity analysis", Review of Income and Wealth, 43, 33-48.

De Gregorio, J. (1993): "Inflation, taxation and long-run growth", Journal of Monetary Economics, 31, 271-298. 
De Gregorio, J. and P. Guidotti (1995): "Financial development and economic growth", World Development, 23, 433-48.

De Gregorio, J. and F. Sturzenegger (1994a): "Credit markets and the welfare costs of inflation", NBER Working Paper 4873.

De Gregorio, J. and F. Sturzenegger (1994b): "Financial markets and inflation under imperfect information", IMF Working Paper 94/63.

Dolado, J. and H. Lütkepohl (1996): "Making Wald test work for cointegrated VAR systems", Econometric Review, 15, 369-386.

Espinosa, M. and C. Yip (1996): "An endogenous growth model of money, banking and financial repression", Federal Reserve Bank of Atlanta, Working Paper 96-4.

Fischer, S. (1993): "The role of macroeconomic factors in growth", Journal of Monetary Economics, 32, 485-512.

Galetovic, A. (1994): "Finance and growth: a synthesis and interpretation of the evidence", Board of Governors of the FED, International Finance Discussion Papers 477.

Goldsmith, R. (1969): Financial structure and development, New Haven, Yale University Press.

Greenwood, J. and B. Jovanovic (1990): "Financial development, growth and the distribution of income", Journal of Political Economy, 98, 1076-1107.

Harris, R. (1997): "Stock markets and development: A re-assessment", European Economic Review, 41, 139-14.

Haslag, J. and J. Koo (1999): "Financial repression, financial development and economic growth", Federal Reserve Bank of Atlanta, Research Department, Working Paper, 99-02.

Huybens, E. and B. Smith (1999): "Inflation, Financial Markets and Long-Run Real Activity", Journal of Monetary Economics, 43, 283-315. 
Islam, N. (1995): "Growth empirics: a panel data approach", Quarterly Journal of Economics, $110,1127-1170$.

King, R. and R. Levine (1993a): "Finance and growth: Schumpeter might be right", Quarterly Journal of Economics, 108, 717-737.

King, R. and R. Levine (1993b): "Finance, entrepreneurship and growth: theory and evidence", Journal of Monetary Economics, 32, 513-542.

Knight, M., N. Loayza and D. Villanueva (1993): "Testing the neoclassical theory of economic growth: a panel data approach", IMF staff papers, 40, 512-541.

Kocherlakota, N. (1996): "Inflation and Growth: Commentary", Federal Reserve Bank of St. Louis Review, May/June 1996, 170-172.

Levine, R. (1997): "Financial development and economic growth: views and agenda", Journal of Economic Literature, 35, 688-726.

Levine, R. and D. Renelt (1992): "A sensitivity analysis of cross-country growth regressions", American Economic Review, 82, 942-963.

Levine, R. and S. Zervos (1998): "Stock markets, banks and growth", American Economic Review, 88, 537-558.

Mankiw, N., D. Romer and D. Weil (1992): "A contribution to the empirics of economic growth", Quarterly Journal of Economics, 107, 407-38.

McKinnon, R. (1973): Money and capital in economic development, Washington D.C., Brookings Institution.

Orphanides, A. and R. Solow (1990): "Money, inflation and growth", in B. Friedman and F. Hahn (eds.), Handbook of Monetary Economics, vol. I.

Pagano, M. (1993): "Financial markets and growth: an overview", European Economic Review, 37, 613-622. 
Roubini, N. and X. Sala-i-Martin (1995): "A growth model of inflation, tax evasion and financial repression", Journal of Monetary Economics, 35, 275-301.

Rousseau, P. and P. Wachtel (1998): "Equity markets and growth: cross-country evidence on timing and outcomes, 1980-1995", New York University Working Paper S-98-24.

Saint-Paul, G. (1992): "Technological choice, financial markets and economic development", European Economic Review, 36, 763-781.

Shaw, E. (1973): Financial deepening in economic development, New York, Oxford University Press.

Sims, C. (1996): "Inflation and Growth: Commentary", Federal Reserve Bank of St. Louis Review, May/June 1996, 173-178.

Sims, C., J. Stock and M. Watson (1990): "Inference in linear time series models with some unit roots", Econometrica, 58, 113-144. 
TABLE 1

DESCRIPTIVE STATISTICS: WHOLE SAMPLE ${ }^{(a)}$

PANEL A

AVERAGE LEVEL OF FINANCIAL INDICATORS AND INFLATION

BY SUBSAMPLES DEFINED IN TERMS OF GROWTH

\begin{tabular}{cccccc}
\hline & $\begin{array}{c}\text { Very } \\
\text { Low }\end{array}$ & Low & High & $\begin{array}{l}\text { Very } \\
\text { High }\end{array}$ & Correlation with Growth \\
\hline OUTPUT GROWTH & -0.6 & 2.0 & 3.5 & 6.1 & - \\
INFLATION & 8.5 & 7.1 & 6.2 & 6.0 & -0.21 \\
DCPY & 59 & 56 & 52 & 48 & -0.13 \\
QLLY & 42 & 42 & 38 & 35 & -0.14 \\
BTOT & 91 & 92 & 91 & 91 & 0.02 \\
RESERVES & 7.0 & 6.7 & 7.1 & 8.1 & 0.05 \\
\hline
\end{tabular}

PANEL B

AVERAGE LEVEL OF FINANCIAL INDICATORS AND GROWTH

BY SUBSAMPLES DEFINED IN TERMS OF INFLATION

\begin{tabular}{|c|c|c|c|c|c|}
\hline & Very & Low & High & Very & Correlation with Inflation \\
\hline & Low & & & High & \\
\hline INFLATION & 2.1 & 4.5 & 7.1 & 14.1 & - \\
\hline OUTPUT GROWTH & 2.9 & 3.5 & 2.8 & 1.8 & -0.21 \\
\hline DCPY & 62 & 54 & 53 & 44 & -0.16 \\
\hline QLLY & 41 & 39 & 39 & 39 & 0.01 \\
\hline ВTOT & 92 & 92 & 92 & 88 & -0.26 \\
\hline RESERVES & 6.4 & 6.2 & 6.4 & 9.9 & 0.28 \\
\hline
\end{tabular}

(a) The whole sample includes 21 countries over the 1961-1993. See Appendix 1 for a list of the countries and for definitions of the variables. 
TABLE 2

DESCRIPTIVE STATISTICS: RESTRICTED SAMPLE ${ }^{(a)}$

PANEL A

AVERAGE LEVEL OF FINANCIAL INDICATORS AND INFLATION BY SUBSAMPLES DEFINED IN TERMS OF GROWTH

\begin{tabular}{cccccc}
\hline & $\begin{array}{c}\text { Very } \\
\text { Low }\end{array}$ & Low & High & $\begin{array}{l}\text { Very } \\
\text { High }\end{array}$ & Correlation with Growth \\
\hline OUTPUT GROWTH & -1.0 & 1.3 & 2.7 & 4.5 & - \\
INFLATION & 8.0 & 6.3 & 6.3 & 6.7 & -0.07 \\
DCPY & 67 & 67 & 63 & 62 & -0.09 \\
QLLY & 47 & 47 & 44 & 45 & -0.08 \\
BTOT & 94 & 94 & 93 & 93 & -0.05 \\
RESERVES & 4.5 & 4.5 & 5.8 & 5.6 & 0.09 \\
MKTCAP & 29 & 28 & 30 & 31 & -0.01 \\
\hline
\end{tabular}

PANEL B

AVERAGE LEVEL OF FINANCIAL INDICATORS AND GROWTH BY SUBSAMPLES DEFINED IN TERMS OF INFLATION

\begin{tabular}{cccccc}
\hline & $\begin{array}{c}\text { Very } \\
\text { Low }\end{array}$ & Low & High & $\begin{array}{l}\text { Very } \\
\text { High }\end{array}$ & Correlation with Inflation \\
\hline INFLATION & 2.1 & 4.6 & 7.4 & 13.2 & - \\
OUTPUT GROWTH & 1.9 & 2.0 & 2.3 & 1.4 & -0.07 \\
DCPY & 83 & 69 & 56 & 51 & -0.36 \\
QLLY & 53 & 47 & 43 & 39 & -0.27 \\
BTOT & 97 & 96 & 92 & 90 & -0.43 \\
RESERVES & 3.4 & 4.7 & 6.0 & 6.4 & 0.28 \\
MKTCAP & 44 & 30 & 26 & 17 & -0.37 \\
\hline
\end{tabular}

(a) The restricted sample includes 16 countries over the 1971-1993. See Appendix 1 for a list of the countries and for definitions of the variables. 
TABLE 3

CONTEMPORANEOUS CORRELATIONS AMONG FINANCIAL INDICATORS

PANEL A

WHOLE SAMPLE

\begin{tabular}{ccccc}
\hline & QLLY & DCPY & BTOT & RESERVES \\
\hline QLLY & - & 0.78 & 0.30 & -0.08 \\
DCPY & & - & 0.52 & -0.14 \\
BTOT & & & - & -0.43 \\
RESERVES & & & & - \\
\hline
\end{tabular}

PANEL B

RESTRICTED SAMPLE

\begin{tabular}{cccccc}
\hline & MKTCAP & QLLY & DCPY & BTOT & RESERVES \\
\hline MKTCAP & - & 0.57 & 0.51 & 0.19 & -0.24 \\
QLLY & & - & 0.81 & 0.38 & -0.11 \\
DCPY & & & - & 0.48 & 0.02 \\
BTOT & & & & - & -0.25 \\
RESERVES & & & & & - \\
\hline
\end{tabular}


TABLE 4. CAUSALITY RESULTS

Panel A

\begin{tabular}{|c|c|c|c|c|}
\hline \multirow[b]{3}{*}{$P$} & \multicolumn{4}{|c|}{ Causality from inflation to } \\
\hline & \multicolumn{2}{|c|}{ Output } & \multicolumn{2}{|c|}{ BTOT } \\
\hline & $F(\%)$ & $t$ & $F(\%)$ & $t$ \\
\hline 3 & 0 & -3.73 & 42 & -0.59 \\
\hline 4 & 0 & -2.32 & 54 & -0.10 \\
\hline 5 & 0 & -3.22 & 50 & -1.14 \\
\hline
\end{tabular}

\begin{tabular}{cccc}
\multicolumn{3}{c}{ Causality from output to } \\
\multicolumn{2}{c}{ Inflation } & \multicolumn{3}{c}{ BTOT } \\
\hline$F(\%)$ & $T$ & $F(\%)$ & $T$ \\
\hline 0 & 1.83 & 69 & 0.78 \\
0 & 5.39 & 51 & 0.78 \\
0 & 1.27 & 27 & -1.63
\end{tabular}

\begin{tabular}{cccc}
\multicolumn{3}{c}{ Causality from BTOT to } \\
\hline \multicolumn{2}{c}{ Output } & \multicolumn{2}{c}{ Inflation } \\
\hline$F(\%)$ & $t$ & $F(\%)$ & $T$ \\
\hline 6 & 0.88 & 35 & -0.11 \\
1 & -1.46 & 4 & -1.84 \\
0 & 1.67 & 6 & -2.45
\end{tabular}

Panel B

\begin{tabular}{cccccc}
\hline & \multicolumn{3}{c}{ Causality from inflation to } \\
\cline { 2 - 6 } & & \multicolumn{2}{c}{ Output } & \multicolumn{2}{c}{ QLLY } \\
\cline { 3 - 6 } & & $F(\%)$ & $t$ & $F(\%)$ & $t$ \\
\cline { 3 - 6 } 3 & 0 & -4.61 & 17 & -1.20 \\
4 & 0 & -3.83 & 29 & 0.35 \\
5 & 0 & -4.93 & 0.52 & 0.08
\end{tabular}

\begin{tabular}{cccc}
\multicolumn{3}{c}{ Causality from output to } \\
\hline \multicolumn{2}{c}{ Inflation } & \multicolumn{2}{c}{ QLLY } \\
\hline$F(\%)$ & $T$ & $F(\%)$ & $T$ \\
\hline 0 & 1.52 & 17 & -1.11 \\
0 & 4.81 & 34 & -0.80 \\
0 & 0.36 & 40 & 0.62
\end{tabular}

\begin{tabular}{cccc}
\multicolumn{3}{c}{ Causality from QLLY to } \\
\hline \multicolumn{2}{c}{ Output } & \multicolumn{2}{c}{ Inflation } \\
\hline $\mathrm{F}(\%)$ & $\mathrm{t}$ & $\mathrm{F}(\%)$ & $\mathrm{T}$ \\
\hline 25 & 0.37 & 0 & 1.54 \\
27 & -0.61 & 0 & $\mathbf{1 . 8 2}$ \\
48 & 0.16 & 0 & 0.56
\end{tabular}

Panel C

\begin{tabular}{|c|c|c|c|c|c|c|c|c|c|c|c|c|}
\hline \multirow[b]{3}{*}{$P$} & \multicolumn{4}{|c|}{ Causality from inflation to } & \multicolumn{4}{|c|}{ Causality from output to } & \multicolumn{4}{|c|}{ Causality from DCPY to } \\
\hline & \multicolumn{2}{|c|}{ Output } & \multicolumn{2}{|c|}{ DCPY } & \multicolumn{2}{|c|}{ Inflation } & \multicolumn{2}{|c|}{ DCPY } & \multicolumn{2}{|c|}{ Output } & \multicolumn{2}{|c|}{ Inflation } \\
\hline & $F(\%)$ & $\mathrm{t}$ & $F(\%)$ & $\mathrm{T}$ & $F(\%)$ & $\mathrm{T}$ & $F(\%)$ & $\mathrm{T}$ & $F(\%)$ & $\mathrm{t}$ & $F(\%)$ & $\mathrm{T}$ \\
\hline 3 & 0 & -3.68 & 20 & -1.54 & 0 & 1.91 & 12 & -0.57 & 9 & -0.62 & 1 & 1.88 \\
\hline 4 & 1 & -2.56 & 37 & -0.07 & 0 & 5.26 & 13 & -0.19 & 14 & -1.78 & 4 & 1.28 \\
\hline \multirow[t]{4}{*}{5} & 0 & -3.39 & 18 & -1.84 & 0 & 0.98 & 21 & 0.30 & 21 & -1.28 & 5 & 0.40 \\
\hline & \multicolumn{12}{|c|}{ Panel D } \\
\hline & \multicolumn{4}{|c|}{ Causality from inflation to } & \multicolumn{4}{|c|}{ Causality from output to } & \multicolumn{4}{|c|}{ Causality from MKTCAP to } \\
\hline & \multicolumn{2}{|c|}{ Output } & \multicolumn{2}{|c|}{ MKTCAP } & \multicolumn{2}{|c|}{ Inflation } & \multicolumn{2}{|c|}{ MKTCAP } & \multicolumn{2}{|c|}{ Output } & \multicolumn{2}{|c|}{ Inflation } \\
\hline$P$ & $F(\%)$ & $\mathrm{t}$ & $F(\%)$ & $\mathrm{T}$ & $F(\%)$ & $\mathrm{T}$ & $F(\%)$ & $\mathrm{T}$ & $F(\%)$ & $t$ & $F(\%)$ & $\mathrm{T}$ \\
\hline 3 & 0 & -2.90 & 5 & -1.92 & 0 & 2.69 & 3 & -2.54 & 0 & 4.37 & 13 & -0.86 \\
\hline 4 & 1 & -2.88 & 36 & -1.20 & 0 & 3.87 & 9 & -1.42 & 0 & 2.86 & 6 & 2.05 \\
\hline 5 & 3 & -1.32 & 18 & -1.26 & 0 & 1.85 & 19 & -0.08 & 0 & 2.44 & 15 & 0.83 \\
\hline
\end{tabular}

Note: The model includes individual effects, accumulation rates (investment rate, schooling, rate of growth of population and a trend) and some macroeconomic indicators lagged t-1 (money growth, exports growth and public spending as a percentage of GDP). $F(\%)$ indicates the $p$-value of the $F$ exclusion test described in the text. 
TABLE 5

\section{CONVERGENCE EQUATION WITH INFLATION AND FINANCIAL INDICATORS (OLS)}

\begin{tabular}{|c|c|c|c|c|c|c|c|c|}
\hline Variable & (1) & (2) & (3) & (4) & (5) & (6) & (7) & (8) \\
\hline INFLATION & -- & -- & -- & -- & $\begin{array}{c}-0.0041 \\
(4.80)\end{array}$ & $\begin{array}{c}-0.0037 \\
(4.32)\end{array}$ & $\begin{array}{c}-0.0039 \\
(4.65)\end{array}$ & $\begin{array}{c}-0.0033 \\
(1.76)\end{array}$ \\
\hline QLLY & $\begin{array}{l}0.008 \\
(0.28)\end{array}$ & -- & -- & -- & $\begin{array}{l}0.015 \\
(0.61)\end{array}$ & -- & -- & -- \\
\hline BTOT & -- & $\begin{array}{l}0.130 \\
(2.40)\end{array}$ & -- & -- & -- & $\begin{array}{l}0.074 \\
(1.39)\end{array}$ & -- & -- \\
\hline DCPY & -- & -- & $\begin{array}{l}0.023 \\
(1.31)\end{array}$ & -- & -- & -- & $\begin{array}{l}0.013 \\
(0.77)\end{array}$ & -- \\
\hline MKTCAP & -- & -- & -- & $\begin{array}{l}0.039 \\
(1.64)\end{array}$ & -- & -- & -- & $\begin{array}{l}0.030 \\
(1.26)\end{array}$ \\
\hline $\mathrm{R}^{2}$ & 0.53 & 0.55 & 0.54 & 0.31 & 0.59 & 0.60 & 0.59 & 0.34 \\
\hline $\mathrm{s}$ & 0.050 & 0.049 & 0.050 & 0.040 & 0.047 & 0.047 & 0.047 & 0.039 \\
\hline
\end{tabular}

Notes: (i) Estimation method: OLS. Absolute t-ratios in parentheses. (ii) Other explanatory variables included in the regressions: initial level of per capita income, rate of investment, rate of schooling, growth rate of population, a linear trend and a constant. (iii) The p-value for the F-test of the joint exclusion of QLLY, BTOT and DCPY is $0.11(0.55)$ in an equation excluding (including) the inflation rate. The $p$ value for the F-test of the joint exclusion of QLLY, BTOT, DCPY and MKTCAP is $0.15(0.09)$ in an equation excluding (including) the inflation rate. 
TABLE 6

CONVERGENCE EQUATION WITH INFLATION AND FINANCIAL INDICATORS (OLS WITH COUNTRY EFFECTS)

\begin{tabular}{|c|c|c|c|c|c|c|c|c|}
\hline & (1) & (2) & (3) & (4) & (5) & (6) & (7) & (8) \\
\hline INFLATION & -- & -- & -- & -- & $\begin{array}{c}-0.0024 \\
(2.43)\end{array}$ & $\begin{array}{c}-0.0024 \\
(2.41)\end{array}$ & $\begin{array}{c}-0.0030 \\
(3.09)\end{array}$ & $\begin{array}{c}-0.0042 \\
(1.61)\end{array}$ \\
\hline QLLY & $\begin{array}{r}-0.027 \\
(0.60)\end{array}$ & -- & -- & -- & $\begin{array}{l}-0.018 \\
(0.41)\end{array}$ & -- & -- & -- \\
\hline ВTOT & -- & $\begin{array}{l}0.067 \\
(0.97)\end{array}$ & -- & -- & -- & $\begin{array}{l}0.058 \\
(0.84)\end{array}$ & -- & -- \\
\hline DCPY & -- & -- & $\begin{array}{r}-0.079 \\
(2.46)\end{array}$ & -- & -- & -- & $\begin{array}{c}-0.098 \\
(3.09)\end{array}$ & -- \\
\hline MKTCAP & -- & -- & -- & $\begin{array}{l}0.139 \\
(3.18)\end{array}$ & -- & -- & -- & $\begin{array}{l}0.136 \\
(3.14)\end{array}$ \\
\hline $\mathrm{R}^{2}$ & 0.66 & 0.66 & 0.68 & 0.61 & 0.68 & 0.68 & 0.70 & 0.62 \\
\hline$s$ & 0.045 & 0.045 & 0.044 & 0.034 & 0.045 & 0.045 & 0.043 & 0.033 \\
\hline $\begin{array}{l}\text { Notes: (i) Esti } \\
\text { included in the } \\
\text { rate of populati } \\
\text { of } Q L L Y, B T C \\
\text { The } p \text {-value } f \\
(0.002) \text { in an } e\end{array}$ & $\begin{array}{l}\text { ation met } \\
\text { egressior } \\
\text { n, country } \\
\text { and DC } \\
\text { the F-te } \\
\text { uation ex }\end{array}$ & $\begin{array}{l}\text { od: OLS } \\
\text { initial le } \\
\text { ummies } \\
Y \text { is } 0.0 \\
\text { th of the } \\
\text { uding (ir }\end{array}$ & $\begin{array}{l}\text { Absolute } \\
\text { sel of per } \\
\text { and a cons } \\
7 \text { (0.002) } \\
\text { joint excl } \\
\text { cluding) th }\end{array}$ & $\begin{array}{l}\text { ratios i } \\
\text { pita inc } \\
\text { ant. (iii) } \\
n \text { an ec } \\
\text { sion of } \\
\text { inflatio }\end{array}$ & $\begin{array}{l}\text { parenthes } \\
\text { e, rate of } i \\
\text { le } p \text {-value } \\
\text { ation exclu } \\
\text { LLY, BTO } \\
\text { rate. }\end{array}$ & $\begin{array}{l}\text { (ii) Othe } \\
\text { estment, } r \\
\text { r the F-tes } \\
\text { ing (incluc } \\
\text {, DCPY a }\end{array}$ & $\begin{array}{l}\text { explanator } \\
\text { te of schoo } \\
\text { of the joir } \\
\text { ng) the in } \\
\text { d MKTCA }\end{array}$ & $\begin{array}{l}\text { variables } \\
\text { ng, growth } \\
\text { exclusion } \\
\text { ation rate. } \\
\text { is } 0.004\end{array}$ \\
\hline
\end{tabular}


TABLE 7

CONVERGENCE EQUATION WITH INFLATION AND FINANCIAL INDICATORS (IV)

\begin{tabular}{|c|c|c|c|c|c|c|c|c|}
\hline & (1) & (2) & (3) & (4) & (5) & (6) & (7) & (8) \\
\hline INFLATION & -- & -- & -- & -- & $\begin{array}{c}-0.0073 \\
(4.65)\end{array}$ & $\begin{array}{c}-0.0077 \\
(4.05)\end{array}$ & $\begin{array}{c}-0.0070 \\
(4.39)\end{array}$ & $\begin{array}{r}-0.0037 \\
(1.10)\end{array}$ \\
\hline QLLY & $\begin{array}{r}-0.010 \\
(0.02)\end{array}$ & -- & -- & -- & $\begin{array}{c}-0.004 \\
(0.12)\end{array}$ & -- & -- & -- \\
\hline ВTOT & -- & $\begin{array}{l}0.155 \\
(1.64)\end{array}$ & -- & -- & -- & $\begin{array}{r}-0.087 \\
(0.85)\end{array}$ & -- & -- \\
\hline DCPY & -- & -- & $\begin{array}{l}0.021 \\
(0.94)\end{array}$ & -- & -- & -- & $\begin{array}{l}0.002 \\
(0.10)\end{array}$ & -- \\
\hline MKTCAP & -- & -- & -- & $\begin{array}{l}0.001 \\
(0.02)\end{array}$ & -- & -- & -- & $\begin{array}{r}-0.010 \\
(0.31)\end{array}$ \\
\hline$R^{2}$ & 0.40 & 0.42 & 0.40 & 0.24 & 0.55 & 0.55 & 0.55 & 0.28 \\
\hline$S$ & 0.051 & 0.050 & 0.051 & 0.042 & 0.044 & 0.045 & 0.045 & 0.041 \\
\hline
\end{tabular}

Notes: (i) Estimation method: IV. Instruments: constant, trend and first and second order lags of the regressors and second lag of the dependent variable. Absolute t-ratios in parentheses. (ii) Other explanatory variables included in the regressions: initial level of per capita income, rate of investment, rate of schooling, growth rate of population, a linear trend and a constant. (iii) The p-value for the F-test of the joint exclusion of QLLY, BTOT and DCPY is $0.36(0.70)$ in an equation excluding (including) the inflation rate. The $p$-value for the F-test of the joint exclusion of QLLY, BTOT, DCPY and MKTCAP is $0.86(0.58)$ in an equation excluding (including) the inflation rate. 


\section{TABLE 8}

\section{CONVERGENCE EQUATION WITH INFLATION AND FINANCIAL INDICATORS (IV WITH COUNTRY EFFECTS)}

\begin{tabular}{|c|c|c|c|c|c|c|c|c|}
\hline & (1) & (2) & (3) & (4) & (5) & (6) & (7) & (8) \\
\hline INFLATION & -- & -- & -- & -- & $\begin{array}{c}-0.0061 \\
(2.88)\end{array}$ & $\begin{array}{c}-0.0059 \\
(2.32)\end{array}$ & $\begin{array}{c}-0.0064 \\
(3.19)\end{array}$ & $\begin{array}{c}-0.0094 \\
(1.32)\end{array}$ \\
\hline QLLY & $\begin{array}{l}-0.010 \\
(0.12)\end{array}$ & -- & -- & -- & $\begin{array}{l}0.069 \\
(0.77)\end{array}$ & -- & -- & -- \\
\hline ВTOT & -- & $\begin{array}{l}0.218 \\
(1.38)\end{array}$ & -- & -- & -- & $\begin{array}{r}-0.035 \\
(0.19)\end{array}$ & -- & -- \\
\hline DCPY & -- & -- & $\begin{array}{l}-0.001 \\
(0.01)\end{array}$ & -- & -- & -- & $\begin{array}{r}-0.061 \\
(0.88)\end{array}$ & -- \\
\hline MKTCAP & -- & -- & -- & $\begin{array}{l}0.153 \\
(1.29)\end{array}$ & -- & -- & -- & $\begin{array}{l}0.102 \\
(0.83)\end{array}$ \\
\hline $\mathrm{R}^{2}$ & 0.57 & 0.55 & 0.56 & 0.60 & 0.62 & 0.61 & 0.64 & 0.61 \\
\hline$\sigma$ & 0.048 & 0.049 & 0.048 & 0.036 & 0.045 & 0.046 & 0.044 & 0.035 \\
\hline $\begin{array}{l}\text { Notes:(i) Estin } \\
\text { lags of the red } \\
\text { (ii) Other expl } \\
\text { investment, rat } \\
\text { for the F-test c } \\
\text { (including) the } \\
\text { and MKTCAP }\end{array}$ & $\begin{array}{l}\text { ation meth } \\
\text { essors ar } \\
\text { natory val } \\
\text { of schooli } \\
\text { the joint } \\
\text { nflation re } \\
0.24(0.1\end{array}$ & $\begin{array}{l}\text { d: IV. In } \\
\text { d secono } \\
\text { ables inc } \\
\text { g, growth } \\
\text { xclusion } \\
\text { e. The p } \\
\text { e) in an } €\end{array}$ & $\begin{array}{l}\text { struments } \\
\text { lag of th } \\
\text { luded in } \\
\text { rate of po } \\
\text { of QLLY, } \\
\text { value for } \\
\text { quation ex }\end{array}$ & $\begin{array}{l}\text { constant } \\
\text { depend } \\
\text { e regres } \\
\text { dlation, c } \\
\text { rOT and } \\
\text { he F-tes } \\
\text { luding (i }\end{array}$ & $\begin{array}{l}\text { country du } \\
\text { tt variable } \\
\text { ions: initial } \\
\text { untry dumm } \\
\text { JCPY is } 0 \text {. } \\
\text { of the joint } \\
\text { cluding) th }\end{array}$ & $\begin{array}{l}\text { amies anc } \\
\text { Absolute } \\
\text { evel of pe } \\
\text { es and a c } \\
7 \text { (0.04) ir } \\
\text { exclusion }\end{array}$ & $\begin{array}{l}\text { irst and se } \\
\text { atios in pa } \\
\text { capita inco } \\
\text { istant. (iii) T } \\
\text { an equatior } \\
\text { QLLY, BT }\end{array}$ & $\begin{array}{l}\text { ond order } \\
\text { entheses. } \\
\text { e, rate of } \\
\text { e p-value } \\
\text { excluding } \\
\text { T, DCPY }\end{array}$ \\
\hline
\end{tabular}

